\title{
Herbicide - Nutrient Interactions in Soil: A Short Review
}

\author{
Ramdas Kanissery*, Biwek Gairhe, Davie Kadyampakeni and Kelly Morgan
}

University of Florida, USA

Submission: March 22, 2018; Published: April 06, 2018

"Corresponding author: Ramdas Kanissery, University of Florida - IFAS, Southwest Florida REC, 2685 State Road 29 N, Immokalee, Florida, 34142 , USA, Tel: 239658-3455; Email: rkanissery@ufl.edu

\section{Introduction}

The dominant soil factors affecting herbicide fate and degradation include soil physical properties, soil chemistry, and microbial activity. Soil nutrients are intrinsic soil factors that have a direct or indirect impact on the behavior of herbicides in the agro-ecosystem. The presence and concentration of nutrients such as nitrogen, phosphorus, iron, etc. play a vital role in the persistence and degradation of herbicides in the environment. In many instances, soil nutrients compete for herbicide adsorption sites in the soil. The importance of this process is determined by the physical and chemical properties of the herbicide and by soil characteristics. Additionally, several soil macro- and micronutrients function as co-factors necessary for the herbicide degrader's growth and activity [1], stimulating microbes to synthesize the essential enzymatic system to break down the herbicides. Here we present a short review of possible interactions that can occur between herbicides and soil nutrients and the subsequent impacts on the environmental fate of herbicides.

\section{Competition for adsorption sites}

Adsorption, or binding of herbicides to the soil, is of critical importance towards determining the fate of herbicides in the soil environment. Adsorption controls the amount of herbicide present in the soil solution. Soil-adsorbed herbicides are temporarily unavailable for microbial degradation because most microbes cannot utilize herbicides in the adsorbed state [2]. Degradation of herbicides in soil has been found to be inversely correlated with the adsorption capacity of the soil [3]. If adsorption of herbicides is high, degradation will be low, possibly due to reduced microbial bioavailability [4,5]. Ionic or polar herbicides (glyphosate, paraquat, diquat, etc.) possess unique adsorption characteristics in the soil when compared to other herbicides that are dominated by non-polar groups (aliphatic and aromatic carbon). Glyphosate, a widely used post-emergent broad-spectrum herbicide is a small molecule with three polar functional groups (carboxyl, amino, and phosphonate groups) and is actively adsorbed by soil minerals [6]. In most soils within the $\mathrm{pH}$ range of 4 to 8 , glyphosate forms mono- or divalent anions and binds with trivalent cations such as aluminum $\left(\mathrm{Al}^{3+}\right)$ and iron $\left(\mathrm{Fe}^{3+}\right)$ [7]. As phosphate in the soil is chemically similar to glyphosate, they react in a similar way. Consequently, glyphosate and phosphate compete for the binding sites, which may affect glyphosate adsorption, and hence mobility, in phosphate-rich soils [6].

The impact of phosphate on glyphosate adsorption in soil was described shortly after the herbicide's launch into the market [8]. Several studies have confirmed the competitive adsorption of glyphosate and phosphate as well as its substantial variability in behavior in various soils $[9,10]$. A relevant study by Gimsing \& Borggaard [11] on the comparative adsorption of glyphosate and phosphate by iron oxide minerals demonstrated competition and adsorption preference for phosphate. This not only eliminated glyphosate adsorption but also resulted in enhanced mobility (desorption) of the herbicide following the addition of phosphate to the soil. Competition for adsorption sites between glyphosate and phosphate, therefore, seems apparent and may have a severe impact on glyphosate mobility, and consequently its bioavailability. This is particularly notable in agricultural soils that are saturated or nearly saturated with phosphate as a result of excessive phosphorus fertilization over many years [12]. Glyphosate-phosphate competition is of environmental concern because the suppressed glyphosate adsorption on phosphate enriched soil may lead to an increased risk of glyphosate leaching to the aquatic environment.

\section{Formation of Chemical Complexes: Chelation Effect}

Chelation is the binding of chemical molecules (ligands) to a central metal resulting in the formation of a chemical complex [13]. Certain herbicides can act as metal cation chelator which interferes with their uptake and translocation in plants. Recent 
evaluations on the chelating ability of herbicides highlighted the significant role of herbicide molecules as an essential factor in interacting with nutrients in soil and crops.

The reduced availability of nutrients as a result of external (in the soil) or internal (in the plants) interaction of glyphosate with cationic nutrients is observed in production systems that rely heavily on glyphosate for weed management. For example, Eker et al. [14] and Bai et al. [15] found that glyphosate reduced the uptake and translocation of micronutrients such as manganese $(\mathrm{Mn})$ and iron (Fe) in row crops and orchards.

This hindered micronutrient availability to the crops was attributed to the formation of poorly soluble glyphosate- metal complexes in plant tissues and/or rhizosphere [14]. There are several similar studies that note the ability of glyphosate to inhibit the acquisition of micronutrients such as Mn, Fe, zinc (Zn) and boron (B) in plants [16-18].

Impacts of soil nutrients on microbial transformation/ degradation of herbicides. Microorganisms can transform compounds, including herbicides, utilizing alternative electron acceptors such as nitrate $\left(\mathrm{NO}_{3}\right)$, sulfate $\left(\mathrm{SO}_{4} 3-\right)$, and iron $\left(\mathrm{Fe}^{3+}\right)$ $[19,20]$. Soils abundant with these nutrients are a conducive environment for the microorganisms to break down herbicidal compounds. This effect is even more profound in water-saturated or flooded soil conditions. Inundation of the soil results in a succession of heterotrophic microbial communities adapted to utilize a variety of potential electron acceptors other than oxygen. In anaerobic conditions $\mathrm{Fe}^{+}$is often the most abundant potential electron acceptor for the oxidation of organic compounds [21]. The contribution of iron $\left(\mathrm{Fe}^{3+}\right)$ and nitrate $\left(\mathrm{NO}^{3-}\right)$ towards the fate of herbicides have been implied in previous studies [22]. The presence of $\mathrm{NO}^{3-}$ suppressed the degradation of trifluralin. However, degradation rate increased under $\mathrm{Fe}^{3+-}$ reducing conditions. Recently it has been reported that degradation and mineralization of a soil-applied pre-emergent herbicide, metolachlor, coincided with the iron-reducing conditions [23]. The study suggested a probable role of reduced iron $\left(\mathrm{Fe}^{2+}\right)$ in the microbial fate of soil-applied metolachlor under saturated soil conditions. Hance [24] studied the possible impacts of soil nutrients on the degradation of atrazine. In this study, the addition of inorganic salts such as ammonium nitrate, potassium nitrate, and ammonium phosphate significantly increased the microbial transformation of atrazine in soil. Similar observations on herbicidal interactions with nutrients were made by other researchers. Lipthay et al. [25] showed that the mineralization rate of the herbicides 2,4-dichlorophenoxyacetic acid (2,4-D) and mecoprop was significantly increased by the presence of the nutrients including sodium $(\mathrm{Na})$, potassium $(\mathrm{K})$ and magnesium $(\mathrm{Mg})$. In yet another study, the presence of $\mathrm{NO}^{3-}$ resulted in an enhanced metabolism of mecoprop without any lag period [26].

The microbial degradation of the herbicide isoproturon was increased in the presence of nitrogen $(\mathrm{N})$ and phosphorous $(\mathrm{P})$ [27].

\section{Influence of Herbicides on Soil Nutrition and Fertility}

Certain herbicides are noted for altering soil nutrition and fertility. For example, substituted urea herbicides, including fenuron, monuron, diuron, siduron, linuron, and neburon have been found to inhibit soil urease activity [28]. with the concentration of the herbicides and the herbicides and the soil type studied.

Notably, urease activity was inhibited not only by herbicides but also by other agrochemicals, including Mancozeb, a dithiocarbamate fungicide $[29,30]$. These urease-inhibiting pesticides would decrease the eventual conversion of this fertilizer to NO3-, especially in cases where they are applied as a mixture or in close proximity with urea in the soil. Palma et al. [31] showed that such impacts of herbicides on urea mineralization could strongly affect the bioavailability of $\mathrm{N}$ in the soil. However, mild inhibition of urease is beneficial as it prevents occasional $\mathrm{NH}^{4+}$ toxicity problems and reduces the potential $\mathrm{N}$ losses.

High rates of herbicides can affect the nodulation [30] and symbiotic nitrogen fixation in leguminous crops [32], though such impacts are negligible when herbicides are applied at optimal levels [30,33,34]

\section{Conclusion}

The behavior of herbicides in the environment is influenced by the presence of nutrients. Variability in soil nutrient conditions ubiquitous to agro-ecosystems may pose a potential environmental risk in the form of herbicide persistence or conversely, may facilitate herbicide degradation. Although herbicides have been the subjects of much research, their fate remains understudied, particularly under fluctuating soil nutrient conditions in the milieu of a multifaceted agroecosystem. Understanding of herbicide-soil nutrient interactions can potentially explain the reduced activity or inactivation of herbicides seen in some locations and can also have implications for the efficacy of soil residual herbicides and remediation of herbicide contaminated areas.

\section{References}

1. Haws NW, Ball WP, Bouwer EJ (2006) Modeling and interpreting bioavailability of organiccontaminant mixtures in subsurface environments. J Contam Hydrol 82(3-4): 255-292.

2. Ainsworth CC, Frederickson JK, Smith SC (1993) Effect of sorption on the degradation of aromatic acids and bases. In: Linn DM, Carski TH, Brusseau ML, Chang FH, Madison WI, (Eds.), Sorption and Degradation of Pesticides and Organic Chemicals in Soil. Soil Science Society of America, USA, pp. 125-144.

3. Sorensen SR, Schultz A, Jacobsen OS, Aamand J (2006) Sorption, desorption and mineralisation of the herbicides glyphosate and MCPA in samples from two Danish soil and subsurface profiles. Environ Pollut 141(1): 184-194.

4. Sims GK, Wolt JD, Lehmann RG (1992) Bioavailability of sorbed pesticides and other xenobiotic molecules. Proceedings of the International Symposium on Environmental Aspects of Pesticide Microbiology, Sigtuna, Sweden. 
5. Sims GK, Taylor-Lovell S, Tarr G, Maskel S (2009) Role of sorption and degradation in the herbicidal function of isoxaflutole. Pest Manage Sci 65(7): 805-810.

6. Gimsing AL, Borggaard OK, Bang M (2004) Influence of soil composition on adsorption of glyphosate and phosphate by contrasting Danish surface soils. Eur J Soil Sci 55(1): 183-191.

7. Gimsing AL, Borggaard OK (2007) Phosphate and glyphosate adsorption by hematite andferrihydrite and comparison with other variable-charge minerals. Clays Clay Miner 55(1): 108-114.

8. Sprankle P, Meggitt WF, Penner D (1975) Adsorption, mobility and microbial degradation of glyphosate in the soil. Weed Sci 23(3): 229-234.

9. Hance RJ (1976) Adsorption of glyphosate by soils. Pestic Sci 7(4): 363366 .

10. Wang YJ, Zhou DM, Sun RJ (2005) Effects of phosphate on the adsorption of glyphosate on three different types of Chinese soils. J Environ Sci (China) 17(5): 711-715.

11. Gimsing AL, Borggaard OK (2001) Effect of $\mathrm{KCl}$ and $\mathrm{CaCl} 2$ as background electrolytes on the competitive adsorption of glyphosate and phosphate on goethite. Clays Clay Miner 49(3): 270-275.

12. Hart MR, Quin BF, Nguyen ML (2004) Phosphorus runoff from agricultural land and direct fertilizer effects: a review. J Environ Qual 33(6): 1954-1972.

13. Weil RR, Brady NC (2016) The nature and properties of soils. Pearson, Columbus, Spain, p. 1104

14. Eker S, Ozturk L, Yazici A, Erenoglu B, Romheld V, et al. (2006) Foliar-applied glyphosate substantially reduced uptake and transport of iron and manganese in sunflower (Helianthus annuus L.) plants. J Agric Food Chem 54(26): 10019-10025.

15. Bai C, Reilly CC, Wood BW (2006) Nickel deficiency disrupts metabolism of ureides, amino acids, and organic acids of young pecan foliage. Plant Physiol 140(2): 433-443.

16. Cakmak I, Yazici A, Tutus Y, Ozturk L (2009) Glyphosate reduced seed and leaf concentrations of calcium, manganese, magnesium, and iron in non-glyphosate resistant soybean. Eur J Agron 31(3): 114-119.

17. Su YS, Ozturk L, Cakmak I, Budak H (2009) Turfgrass species response exposed to increasing rates of glyphosate application. Eur J Agron 31(3): 120-125.

18. Tesfamariam T, Bott S, Cakmak I, Römheld V, Neumann G (2009) Glyphosate in the rhizosphere-Role of waiting times and different glyphosate binding forms in soils for phytotoxicity to non-target plants. Eur J Agron 31(3): 126-132.

19. Anderson RT, Lovely DR (1997) Ecology and biogeochemistry of in situ ground water bioremediation. In: Jones JG (Ed.), Advances in Microbial Ecology. Advancements in Microbial Ecology 15: 289-350.

This work is licensed under Creative Commons Attribution 4.0 License DOI: 10.19080/ARTOAJ.2018.15.555951
20. Lovely DR (2001) Anaerobes to the rescue. Science 293(5534): 14441446.

21. Lovely DR (1991) Dissimilatory Fe (III) and Mn (IV) reduction. Microbiol Rev 55(2): 259-287.

22. Tor JM, Xu C, Stucki MJ, Wander MM, Sims GK (2000) Trifluralin degradation under microbiologically induced nitrate and Fe(III) reducing conditions. Environ Sci Technol 34(15): 3148-3152.

23. Kanissery RG (2014) Bioavailability of metolachlor and glyphosate in aerobic and anaerobic soils. University of Illinois at Urbana-Champaign.

24. Hance RJ (1973) The effect of nutrients on the decomposition of the herbicides atrazine and linuron incubated with soil. Pestic Sci 4(6): 817-822.

25. Lipthay JR, Sørensen SR, Aamand J (2007) Effect of herbicide concentration and organic and inorganic nutrient amendment on the mineralization of mecoprop, 2, 4-D and 2, 4, 5-T in soil and aquifer samples. Environ Pollut 148(1): 83-93.

26. Harrison I, Williams GM, Carlick CA (2003) Enantioselective biodegradation of mecoprop in aerobic and anaerobic microcosms. Chemosphere 53(5): 539-549.

27. Perrin-Ganier C, Schiavon F, Morel JL, Schiavon M (2001) Effect of sludge-amendment or nutrient addition on the biodegradation of the herbicide isoproturon in soil. Chemosphere 44(4):887-892.

28. Cervelli S, Nannipieri P, Giovanni G, Perna A (1976) Relationships between substituted urea herbicides and soil urease activity. Weed Research 16(6): 365-368.

29. Domsch KH, Jagnow G, Anderson TH (1983) An ecological concept for the assessment of side-effects of agrochemicals on soil microorganisms. In: Gunther FA (Ed.), Residue Reviews. Residue Reviews 86. Springer, New York, USA.

30. Moorman TB (1989) A review of pesticide effects on microorganisms and microbial processes related to soil fertility. J Prod Agric 2(1): 1423.

31. Palma G, Jorquera M, Demanet R, Elgueta S, Briceno G, et al. (2016) Urea fertilizer and $\mathrm{pH}$ influence on sorption process of Flumetsulam and MCPA acidic herbicides in a volcanic soil. J Environ Qual 45(1): 323-330.

32. Bethlenfalvay GJ, Norris RF, Phillips DA (1979) Effect of bentazon, a Hill reaction inhibitor, on nitrogen-fixing capability and apparent photosynthesis. Plant Physiol 63(1): 213-215.

33. Kapusta G, Rouwenhorst DL (1973) Interaction of selected pesticides and Rhizobium japonicum in pure culture and under field conditions. Agron J 65(1): 112-115.

34. Moorman TB (1986) Effects of herbicides on the survival of Rhizobium japonicum strains. Weed Science 34(4): 628-633.

Your next submission with Juniper Publishers will reach you the below assets

- Quality Editorial service

- Swift Peer Review

- Reprints availability

- E-prints Service

- Manuscript Podcast for convenient understanding

- Global attainment for your research

- Manuscript accessibility in different formats

( Pdf, E-pub, Full Text, Audio)

- Unceasing customer service

Track the below URL for one-step submission https://juniperpublishers.com/online-submission.php 
